\title{
KORBAN KECELAKAAN LALU LINTAS SEPEDA MOTOR DI KOTA BANDUNG
}

\author{
An An Anisarida \\ Universitas Winaya Mukti \\ Jln. Pahlawan No. 69 \\ Bandung \\ anananisarida@unwim.ac.id
}

\author{
Wimpy Santosa \\ Program Doktor Ilmu Teknik Sipil \\ Universitas Katolik Parahyangan \\ Jln. Merdeka No. 30, Bandung \\ wimpy@unpar.ac.id
}

\begin{abstract}
The number of traffic accidents, including motorcycle traffic accidents in the City of Bandung in 2013-2017 tends to decrease. However, traffic accidents involving motorbikes still dominate traffic accidents that occur. The proportion of traffic accidents involving motorbikes is still the highest compared to those of other traffic accidents, and reaches a maximum in 2015 , which is $93 \%$ of the number of traffic accidents in the City of Bandung. In addition, the chance of death in motorcycle traffic accidents is still relatively high, which is between $9 \%$ and $21 \%$. The high chance of death victims requires a more in-depth study to improve traffic safety, especially in motorcycle use.
\end{abstract}

Keywords: traffic accidents, motorcycle traffic accidents, traffic accident victims, traffic safety

\begin{abstract}
Abstrak
Jumlah kecelakaan lalu lintas, termasuk kecelakaan lalu lintas sepeda motor di Kota Bandung pada tahun 20132017 cenderung mengalami penurunan. Walaupun demikian, kecelakaan lalu lintas yang melibatkan sepeda motor masih mendominasi kecelakaan lalu lintas yang terjadi. Proporsi kecelakaan lalu lintas yang melibatkan sepeda motor masih yang terbesar dibandingkan dengan kejadian kecelakaan lalu lintas yang lain, dan mencapai maksimum pada tahun 2015, yaitu 93\% terhadap jumlah kecelakaan lalu lintas di Kota Bandung. Selain itu, peluang terjadinya korban meninggal dunia dalam kecelakaan lalu lintas sepeda motor masih relatif tinggi, yaitu antara 9\% hingga 21\%. Tingginya peluang terjadinya korban meninggal dunia ini membutuhkan penelitian yang lebih mendalam untuk meningkatkan keselamatan berlalu lintas, khususnya dalam penggunaan sepeda motor.
\end{abstract}

Kata-kata kunci: kecelakaan lalu lintas, kecelakaan lalu lintas sepeda motor, korban kecelakaan lalu lintas, keselamatan lalu lintas

\section{PENDAHULUAN}

Berdasarkan data dari tahun 2013 sampai dengan tahun 2017, jumlah kecelakaan lalu lintas di Kota Bandung mengalami penurunan (Polrestabes Kota Bandung, 2018). Jumlah ratarata per tahun korban kecelakaan lalu lintas di Kota Bandung adalah 116 korban meninggal dunia (MD), 24 korban luka berat (LB), dan 756 korban luka ringan (LR).

Sepeda motor merupakan kendaraan bermotor beroda dua atau tiga tanpa rumahrumah, baik dengan atau tanpa kereta samping. Sepeda motor sebagai salah satu alat transportasi merupakan sarana yang cukup dominan di Indonesia. Jumlah sepeda motor yang tercatat pada tahun 2016 di Kota Bandung adalah 462.479 buah (BPS, 2016). 
Di banyak negara berkembang, sepeda motor merupakan salah satu moda yang potensial dan bersahabat dengan masyarakat, terutama masyarakat kalangan menengah ke bawah. Pengendara sepeda motor merupakan pengguna jalan yang paling cepat berkembang secara global dan mewakili peningkatan proporsi kecelakaan di jalan di dunia (Roger, 2008). Pengguna sepeda motor, baik pengendara maupun pembonceng, merupakan pengguna jalan yang paling mudah menjadi korban bila terjadi kecelakaan (ADB, 1996).

Seperti halnya dengan pengguna jalan yang lain, pengendara sepeda motor harus mematuhi peraturan yang berlaku, yaitu Undang-Undang Nomor 22 Tahun 2009 tentang Lalu Lintas dan Angkutan Jalan. Adapun yang diatur dalam undang-undang tersebut meliputi: (1) setiap pengendara sepeda motor di jalan harus memiliki Surat Izin Mengemudi (SIM) untuk sepeda motor dan mampu mengemudikan kendaraannya dengan wajar, (2) pengendara sepeda motor wajib mengutamakan keselamatan pejalan kaki, (3) pengendara sepeda motor mengetahui tata cara berlalu lintas di jalan, (4) sepeda motor hanya dimaksudkan untuk digunakan oleh dua orang, (5) sepeda motor memenuhi persayaratan teknis dan laik jalan apabila digunakan di jalan, serta (6) pengemudi dan penumpang wajib menggunakan helm yang telah direkomendasikan keselamatannya dan terpasang dengan benar.

Khusus untuk kecelakaan sepeda motor di Kota Bandung, jumlah kecelakaan lalu lintas juga menurun, dengan korban MD mencapai rata-rata 103 korban per tahun, LB sebesar 19 korban per tahun, dan LR sebesar 688 korban per tahun. Meningkatnya jumlah korban meninggal dunia ini sejalan dengan meningkatnya jumlah populasi dan jumlah kepemilikan kendaraan bermotor di Kota Bandung saat ini.

Studi-studi yang pernah dilakukan menunjukkan bahwa tingkat fatalitas sepeda motor jauh lebih tinggi daripada tingkat fatalitas kendaraan lainnya. Hasil studi di Inggris menyatakan bahwa tingkat kematian kecelakaan sepeda motor per mil-kendaraan adalah 20 kali lipat daripada tingkat kematian untuk kecelakaan mobil. Tingkat cedera kecelakaan sepeda motor juga 3 kali lebih besar dibandingkan tingkat cedera kecelakaan mobil. Hasil penelitian ini dapat dimengerti dengan alasan: (1) pengemudi sepeda motor secara keseluruhan memiliki kemungkinan untuk mengambil lebih banyak risiko, (2) pengendara sepeda motor tidak dilengkapi dengan bantalan udara dan tidak terlindung oleh badan kendaraan, dan (3) pengendara sepeda motor memiliki kemungkinan terlempar ke depan dengan kecepatan yang sama dengan kecepatan kendaraan ketika tabrakan terjadi, yang umumnya kepala pengguna sepeda motor membentur objek tetap terlebih dahulu atau tergelincir sampai berhenti dan kejadian ini berisiko menimbulkan cedera atau kematian.

Kecelakaan sepeda motor tidak saja menimbulkan kerugian material, tetapi mengakibatkan kehilangan sumber daya manusia yang sangat tinggi. Karena itu, kecelakaan lalu lintas memerlukan perhatian serius, agar jumlah korban kecelakaan dan kerugian material yang ditimbulkan dapat dikurangi.

Keselamatan pengendara sepeda motor akan memengaruhi perekonomian keluarga dan masyarakat. Pengendara sepeda motor yang menjadi korban kecelakaan lalu lintas, sebagian besar merupakan pencari nafkah keluarga. Korban meninggal dunia membuat 
keluarga yang ditinggalkan menderita kerugian ditinjau dari perekonomian (Direktorat Jenderal Bina Marga, 2012).

Tujuan penelitian ini adalah untuk memberikan gambaran permasalahan jumlah kecelakaan dengan tingkat keparahan (severity) yang terjadi. Kecelakaan lalu lintas ini dapat dibagi menjadi beberapa macam, yaitu: (1) kecelakaan dengan korban, yang terdiri atas meninggal dunia, luka berat, dan luka ringan, serta (2) kecelakaan tanpa korban atau hanya berupa kerusakaan material.

Studi ini dilakukan dengan melakukan analisis terhadap data yang diperoleh secara deskriptif menggunakan analisis satu dimensi (Tjahjono et al., 2018), untuk menggambarkan jumlah kecelakaan dan tingkat keparahan korban yang terjadi pada kecelakaan sepeda motor di Kota Bandung setiap tahun. Data yang dianalisis secara deskriptif meliputi data korban meninggal dunia, luka berat, dan luka ringan. Korban kecelakaan dikelompokkan untuk mengetahui jumlah kecelakaan sepeda motor, proporsi kecelakaan sepeda motor terhadap kecelakaan yang terjadi di Kota Bandung, dan jumlah korban yang sering terjadi dalam kecelakaan sepeda motor.

Kecelakaan lalu lintas adalah suatu peristiwa di jalan yang tidak diduga dan tidak disengaja yang melibatkan kendaraan dengan atau tanpa pengguna jalan lain yang mengakibatkan korban manusia dan/atau kerugian harta benda (Pemerintah Republik Indonesia, 2009). Menurut WHO (2013), kecelakaan lalu lintas merupakan kejadian pada lalu lintas jalan yang sedikitnya melibatkan satu kendaraan yang menyebabkan cedera atau kerusakan atau kerugian pada pemiliknya. Dari dua definisi kecelakaan lalu lintas tersebut dapat dinyatakan bahwa kecelakaan lalu lintas merupakan suatu kejadian pada lalu lintas jalan yang tidak diduga waktu dan tempat terjadinya dan tidak diinginkan untuk terjadi, dengan melibatkan paling sedikit satu kendaraan dengan atau tanpa pengguna jalan lain yang menyebabkan cedera, trauma, cacat, kematian, dan/atau kerugian harta benda pada pihak yang terlibat.

Kecelakaan lalu lintas dapat diklasifikasikan menjadi 5 jenis, yaitu: (1) kecelakaan berdasarkan korban kecelakaan, (2) kecelakaan berdasarkan lokasi kejadian, (3) kecelakaan berdasarkan waktu terjadinya kecelakaan, (4) kecelakaan berdasarkan posisi kecelakaan, dan (5) kecelakaan berdasarkan jumlah kendaraan yang terlibat (Wedasana, 2011). Kecelakaan berdasarkan korban kecelakaan menitikberatkan pada manusia itu sendiri. Kecelakaan ini dapat berupa luka ringan, luka berat, maupun meninggal dunia. Selanjutnya, kecelakaan lalu lintas dapat terjadi di mana saja di sepanjang suatu ruas jalan, baik pada bagian jalan lurus, di tikungan jalan, di tanjakan atau di turunan, di dataran atau di pegunungan, serta di dalam kota maupun di luar kota. Berdasarkan waktu terjadinya, kecelakaan lalu lintas dapat digolongkan menjadi 2 macam, yaitu: (1) kecelakaan lalu lintas yang terjadi pada hari tertentu, dan (2) kecelakaan lalu lintas yang terjadi pada jam tertentu. Jenis hari terjadinya kecelakaan lalu lintas dibedakan menjadi 2, yaitu hari kerja dan hari libur. Sedangkan jam terjadinya kecelakaan lalu lintas dibedakan menjadi: (1) Dini hari, mulai jam 00.00 sampai jam 06.00; (2) Pagi hari, mulai jam 06.00 sampai jam 12.00; (3) Siang hari, mulai jam 12.00 sampai jam 18.00; dan (4) Malam hari, mulai jam 18.00 sampai jam 24.00. 
Berdasarkan karakteristiknya, suatu tabrakan pada kecelakaan lalu lintas dapat dibagi menjadi 5 jenis (DKTD, 2006). Jenis-jenis tabrakan tersebut adalah: (1) tabrakan antara kendaraan-kendaraan yang bergerak pada arah yang berbeda atau menyudut, tetapi tidak dari arah yang berlawanan; (2) suatu kendaraan menabrak dari arah belakang kendaraan lain yang bergerak searah; (3) suatu kendaraan yang bergerak menabrak kendaraan lain dari bagian samping ketika berjalan pada arah yang sama atau pada arah yang berlawanan; (4) tabrakan antara kendaraan-kendaraan yang bergerak pada arah yang berlawanan; dan (5) tabrakan yang terjadi akibat suatu kendaraan yang bergerak mundur.

Berdasarkan Pasal 229 Undang-Undang Nomor 22 Tahun 2009, kecelakaan lalu lintas dapat dikelompokkan menjadi: (1) Kecelakaan Lalu Lintas Ringan, yaitu kecelakaan lalu lintas yang mengakibatkan kerusakan kendaraan dan/atau barang; (2) Kecelakaan Lalu Lintas Sedang, yaitu kecelakaan lalu lintas yang mengakibatkan luka ringan dan kerusakan kendaraan dan/atau barang; dan (3) Kecelakaan Lalu Lintas Berat, yaitu kecelakaan lalu lintas yang mengakibatkan korban meninggal dunia atau luka berat. Kecelakaan lalu lintas tersebut dapat disebabkan oleh beberapa hal, termasuk kelalaian pengguna jalan, ketidaklaikan kendaraan, serta ketidaklaikan jalan dan/atau lingkungan.

Korban kecelakaan lalu lintas dibagi menjadi 3 macam, yaitu korban mati, korban luka berat, dan korban luka ringan. Korban mati adalah korban kecelakaan lalu lintas yang meninggal dunia sebagai akibat kecelakaan lalu lintas dalam jangka waktu paling lama 30 hari setelah suatu kecelakaan terjadi. Korban luka berat adalah korban kecelakaan lalu lintas yang karena luka-lukanya menderita cacat tetap atau harus dirawat inap di rumah sakit dalam jangka waktu lebih dari 30 hari sejak terjadinya kecelakaan, sedangkan yang dimaksud dengan cacat tetap adalah jika suatu anggota badan hilang atau tidak dapat digunakan sama sekali dan tidak dapat sembuh atau pulih untuk selama-lamanya. Korban luka ringan adalah korban kecelakaan lalu lintas yang mengalami luka-luka, tetapi tidak memerlukan rawat inap atau tidak harus dirawat inap di rumah sakit lebih dari 30 hari.

\section{DATA DAN PEMBAHASAN}

\section{Jumlah Kecelakaan Lalu Lintas}

Data yang ada menunjukkan bahwa jumlah kecelakaan lalu lintas di Kota Bandung cenderung mengalami penurunan dari tahun 2013 (sebanyak 838 kejadian) hingga tahun 2017 (sebanyak 501 kejadian). Pola penurunan jumlah kecelakaan lalu lintas di Kota Bandung ini dapat dilihat pada Gambar 1.

\section{Jumlah Kecelakaan Lalu Lintas Sepeda Motor}

Kecelakaan lalu lintas yang melibatkan sepeda motor yang terjadi di Kota Bandung pada tahun 2013 hingga tahun 2017 di Kota Bandung juga cenderung mengalami penurunan. Pada tahun 2013 terjadi 730 kejadian kecelakaan lalu lintas sepeda motor, yang berkurang pada tahun-tahun selanjutnya, dan pada tahun 2017 mencapai 447 kejadian kecelakaan lalu 
lintas sepeda motor, dengan jumlah rata-rata 614 kejadian kecelakaan lalu lintas sepeda motor per tahun. Gambar 2 menunjukkan jumlah kecelakaan lalu lintas sepeda motor di Kota Bandung dari tahun 2013 hingga tahun 2017.

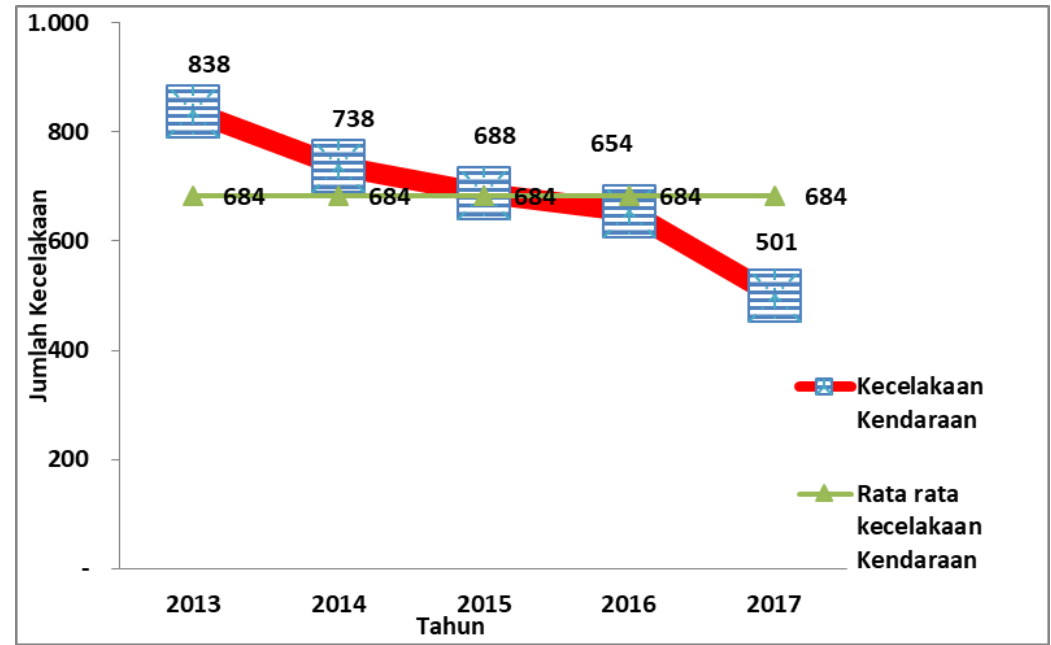

Gambar 1 Jumlah Kecelakaan Lalu Lintas di Kota Bandung

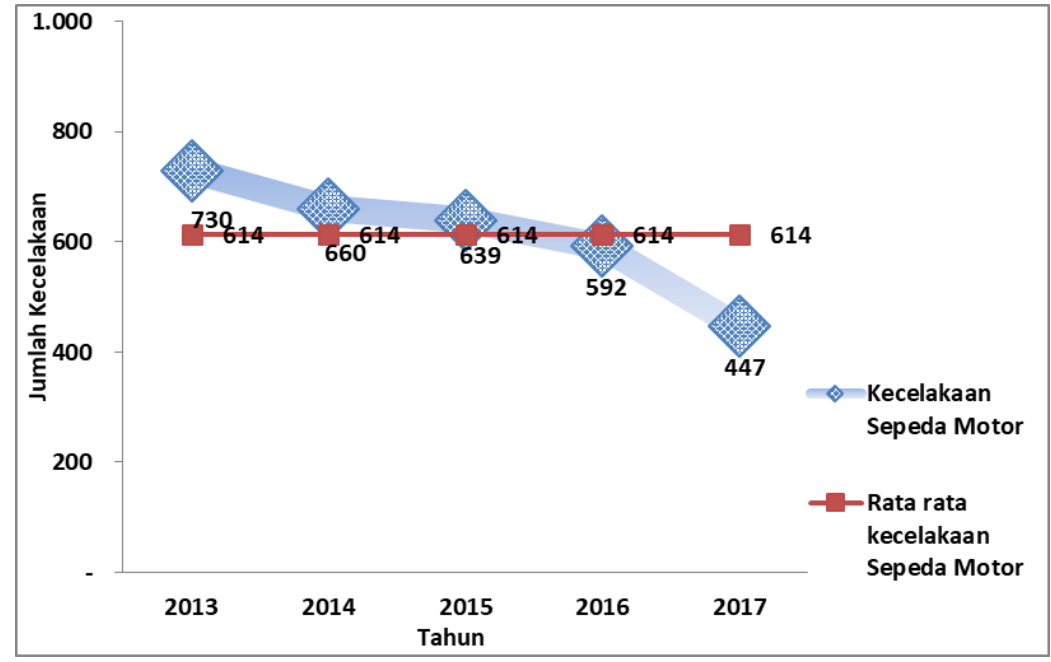

Gambar 2 Jumlah Kecelakaan Sepeda Motor Kota Bandung

\section{Proporsi Jumlah Kecelakaan Lalu Lintas Sepeda Motor}

Jumlah kecelakaan lalu lintas sepeda motor memiliki proporsi terbesar terhadap jumlah kecelakaan lalu lintas yang terjadi Kota Bandung. Proporsi kecelakaan lalu lintas sepeda motor berada pada rentang antara $87 \%$ hingga $93 \%$ terhadap jumlah kecelakaan lalu lintas total pada periode 2013 hingga 2017, seperti terlihat pada Gambar 3. Kecelakaan lalu lintas sepeda motor tersebut dapat disebabkan oleh kombinasi berbagai faktor, termasuk perilaku dan pengalaman pengendara sepeda motor, perilaku pengemudi kendaraan lainnya, serta lingkungan jalan. 


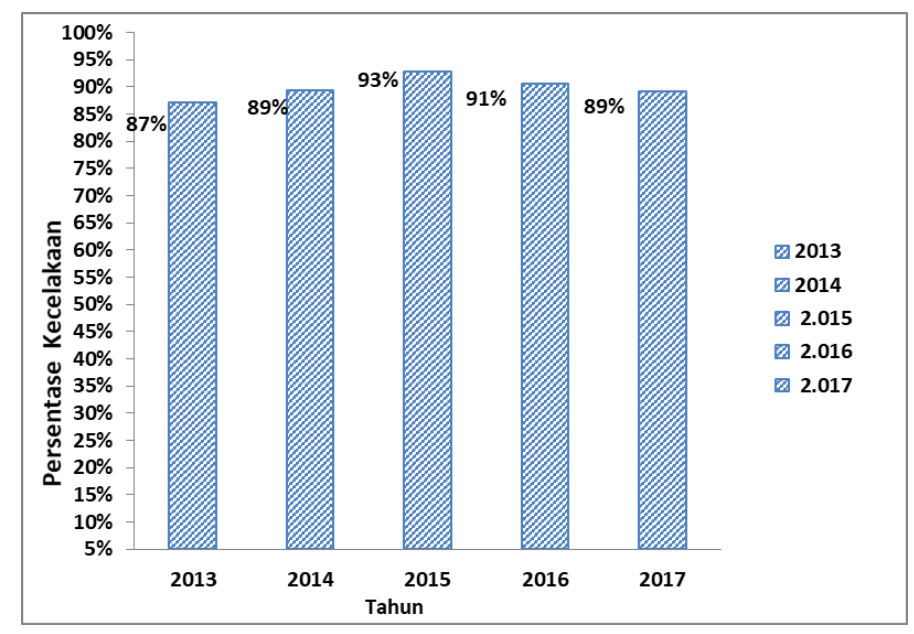

Gambar 3 Proporsi Kecelakaan Sepeda Motor di Kota Bandung

Pada tahun 2015, proporsi jumlah kecelakaan lalu lintas sepeda motor terhadap jumlah kecelakaan lalu lintas total yang terjadi di jalan mencapai nilai terbesar, yaitu 93\% (lihat Gambar 3). Data yang ada ini mengindikasikan bahwa sepeda motor merupakan moda transportasi yang mendominasi kecelakaan lalu lintas di Kota Bandung.

Pengendara sepeda motor juga dikenal sebagai pengguna jalan yang paling rentan terhadap terjadinya kecelakaan lalu lintas, karena sepeda motor tidak mempunyai perlindungan yang dimiliki oleh mobil atau kendaraan lain. Selain itu, seringkali saat berada di jalan sepeda motor kurang mencolok atau kurang menarik perhatian, sehingga keberadaannya sulit untuk diketahui oleh pengemudi mobil atau pengemudi truk.

\section{Jumlah Korban Meninggal Dunia}

Proporsi jumlah korban kecelakaan lalu lintas sepeda motor merupakan yang terbesar dibandingkan dengan proporsi korban kecelakaan lalu lintas yang lain yang terjadi di Kota Bandung, seperti yang dapat dilihat pada Gambar 4. Jumlah kejadian kecelakaan lalu lintas sepeda motor di Kota Bandung cenderung menurun, tetapi jumlah kematian akibat kecelakaan sepeda motor ini tetap tinggi dan bahkan meningkat dari 75 korban pada tahun 2016 menjadi 127 korban pada tahun 2017. Pada studi ini belum dapat diketahui mengapa jumlah korban kecelakaan lalu lintas sepeda motor ini meningkat, sehingga masih diperlukan investigasi yang lebih jauh untuk menjawab hal tersebut.

Pada Gambar 4 terlihat bahwa jumlah korban luka berat kecelakaan lalu lintas sepeda motor merupakan yang paling sedikit dibandingkan dengan jumlah korban kecelakaan lalu lintas sepeda motor yang lain. Umumnya korban luka berat disebabkan tidak disiplinnya pengguna sepeda motor dalam pemakaian helm, penggunaan helm yang tidak memenuhi syarat, atau tidak mengenakan helm.

Untuk kecelakaan lalu lintas sepeda motor di Kota Bandung, peluang terjadinya korban meninggal dunia berada pada rentang 9\% (75 meninggal dari 792 kejadian pada tahun 2016) hingga 21\% (127 meninggal dari 602 kejadian pada tahun 2017). Dari tahun 2013 hingga tahun 2016 peluang terjadinya korban meninggal dunia ini berkisar pada 
rentang $9 \%$ hungga $12 \%$, dan mengalami peningkatan yang signifikan pada tahun 2017 . Untuk itu, sekali lagi, diperlukan kajian yang lebih mendalam untuk mencari penyebab meningkatnya proporsi korban meninggal dunia akibat kecelakaan lalu lintas sepeda motor ini.

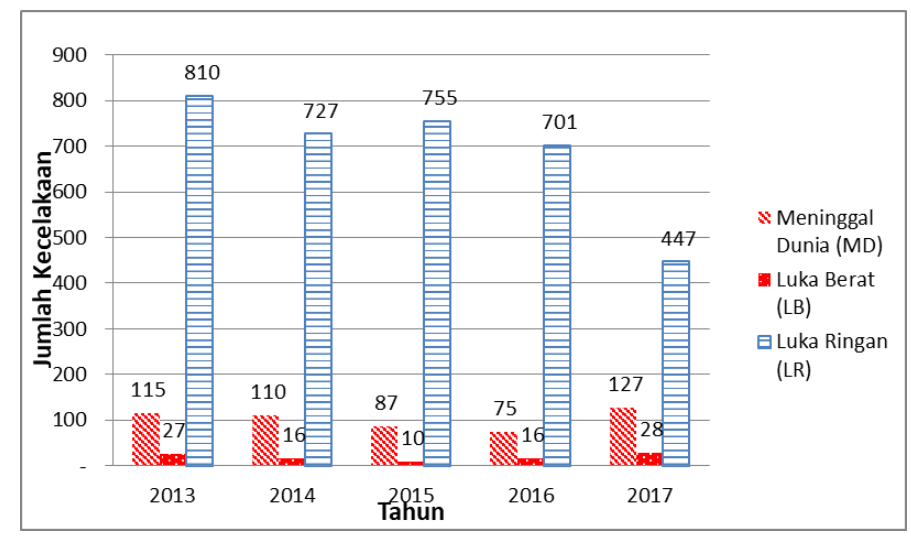

Gambar 4 Jumlah Korban Kecelakan Sepeda Motor

Pada Gambar 5 terlihat bahwa rata-rata kecelakaan lalu lintas sepeda motor di Kota Bandung berada pada rentang 37 sampai dengan 61 kejadian kecelakaan lalu lintas per bulan, atau 1 hingga 3 kecelakaan lalu lintas per hari, dengan korban meninggal dunia 6 hingga 11 orang per bulan dan luka ringan 37 hingga 68 orang/bulan. Data yang ada ini menunjukkan rendahnya tingkat keselamatan lalu lintas sepeda motor dan tentunya hal ini membutuhkan upaya-upaya untuk meningkatkan keselamatan berlalu lintas serta meningkatkan kesadaran masyarakat akan pentingnya berkendara sepeda motor secara selamat dan aman.

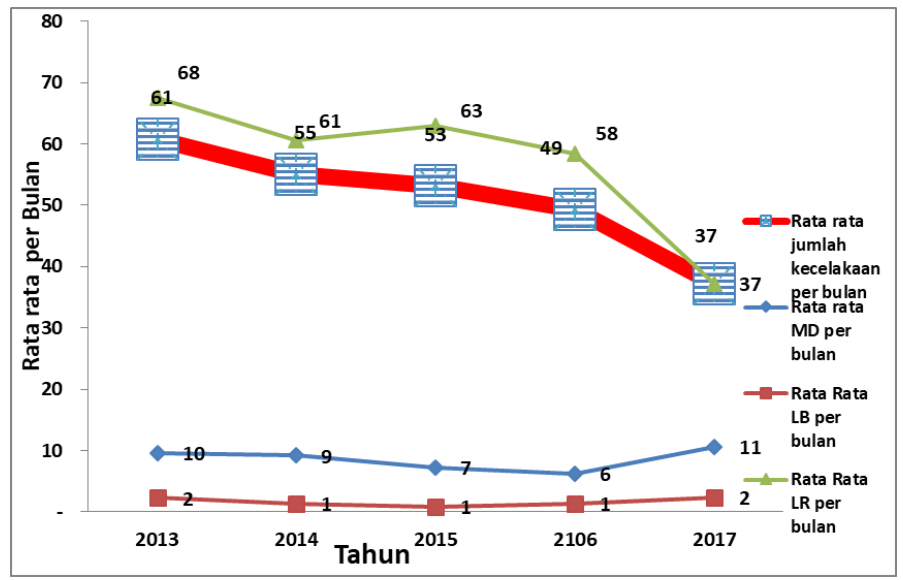

Gambar 5 Rata-Rata Jumlah Kecelakaan Sepeda Motor Per Bulan di Kota Bandung

\section{KESIMPULAN}

Studi ini membahas kecelakaan lalu lintas sepeda motor yang terjadi di Kota Bandung pada kurun waktu dari tahun 2013 hingga tahun 2017. Dari pembahasan yang telah dilakukan dapat ditarik kesimpulan sebagai berikut: 
1) Jumlah kecelakaan lalu litas yang terjadi di Kota Bandung pada tahun 2013 hingga tahun 2017 cenderung mengalami penurunan. Hal serupa juga terjadi pada jumlah kecelakaan lalu lintas sepeda motor. Dari tahun 2013 sampai 2017 sebesar 684 kejadian/tahun, sedangkan jumlah rata-rata kecelakaan sepeda motor dari tahun 2013 sampai tahun 2017 sebesar 614 kejadian/hari.

2) Kecelakaan lalu lintas yang melibatkan sepeda motor mempunyai proporsi yang terbesar dibandingkan dengan kejadian kecelakaan lalu lintas yang lain. Proporsi kejadian kecelakaan lalu lintas sepeda motor mencapai maksimum pada tahun 2015, yaitu 93\% terhadap jumlah kecelakaan lalu lintas di Kota Bandung.

3) Untuk kecelakaan lalu lintas yang melibatkan sepeda motor, peluang terjadinya korban meninggal dunia adalah antara $9 \%$ hingga $21 \%$. Tingginya peluang terjadinya korban meninggal dunia ini membutuhkan penelitian yang lebih mendalam untuk meningkatkan keselamatan berlalu lintas, khususnya dalam penggunaan sepeda motor.

\section{DAFTAR PUSTAKA}

Asian Development Bank (ADB). 1996. Asian Development Outlook 1995 and 1996. New York: Oxford University Press.

Badan Pusat Statistik (BPS) Kota Bandung. 2016. Kota Bandung dalam Angka 2016. Bandung: Badan Pusat Statistik (BPS) Kota Bandung.

Direktorat Keselamatan Transportasi Darat (DKTD). 2006. Manajemen Keselamatan Transportasi Jalan. Direktorat Jenderal Perhubungan Darat, Kementerian Perhubungan. Jakarta.

Direktorat Jenderal Bina Marga. 2012. Panduan Teknik 1 Rekayasa Keselamatan Jalan. Kementerian Pekerjaan Umum. Jakarta.

Kepolisian Resort Kota Besar (Polrestabes) Kota Bandung. 2018. Data Kecelakaan di Kota Bandung Tahun 2013-2017. Bandung.

Pemerintah Republik Indonesia. 2009. Undang-Undang Nomor 22 Tahun 2009 tentang Lalu Lintas dan Angkutan Jalan. Jakarta.

Roger, M. 2008. Highway Engineering. 2nd Ed. Oxford: Blackwell Publishing Ltd.

Tjahjono, T., Siregar, A., dan Kusuma, A. 2018. Pemahaman Data Kecelakaan Lalu Lintas untuk Penelitian dan Kebijakan Keselamatan Jalan. Workshop 4, Simposium FSTPT Ke-21, Universitas Brawijaya, Malang.

Wedasana, A.S. 2011. Analisis Daerah Rawan Kecelakaan dan Penyusunan Database Berbasis Sistem Informasi Geografis: Studi Kasus Kota Denpasar. Denpasar: Program Studi Pascasarjana, Universitas Udayana.

World Health Organization (WHO). 2013. Global Status Report on Road Safety 2013. Geneva. 